\title{
THE CONTENT OF LEAD, CADMIUM AND MERCURY IN SEDIMENTS FROM RAINWATER RESERVOIRS SITUATED ALONG THE NATIONAL ROAD 4
}

\author{
ZAWARTOŚĆ OŁOWIU, KADMU I RTĘCI W OSADACH \\ ZE ZBIORNIKÓW WÓD OPADOWYCH ZLOKALIZOWANYCH \\ WZDŁUŻ DROGI KRAJOWEJ NR 4
}

\begin{abstract}
The paper aimed at determining the pollution level of sediments collected from reservoirs receiving rainwater. The sediments were sampled from11 reservoirs on three dates: in May 2007, in April 2008 and in June 2008 in the following localities: Sulkow, Biskupice, Bodzanow and Suchoraba situated at a distance of ca 15 from each other. The contents of lead, cadmium, mercury and organic matter were assessed in the sediments. Lead content in the analysed sediments ranged from 9.87 to $61 \mathrm{mg} \cdot \mathrm{kg}^{-2}$ with average for all samples $28.08 \mathrm{mg} \cdot \mathrm{kg}^{-1}$. Mean cadmium concentration in the studied sediments was $0.637 \mathrm{mg} \cdot \mathrm{kg}^{-1}$ and fluctuated from 0.20 to $1.58 \mathrm{mg} \mathrm{Cd} \cdot \mathrm{kg}^{-1}$. The quantities of mercury assessed in the sediments from rainwater reservoirs ranged from 0.337 to $0.864 \mathrm{mg} \cdot \mathrm{kg}^{-1}$. Considerable differences between studied metal concentrations were assessed among the studied reservoirs, however the trends of differences were similar at each sampling. Generally, the levels of cadmium and mercury assessed in the analyzed sediments were comparable to the sediments from urbanized areas of various cities in the world, whereas lead level in the sediments of the analysed reservoirs was generally much lower than reported for similar materials in literature. Regularly decreasing contents of all elements with growing distance from the Krakow agglomeration was noted. The reservoir situated closest to Krakow, in Sulkow is located $7 \mathrm{~km}$ from the city boundaries and borders on Wieliczka town, whereas the reservoir in Suchoraba is located $17 \mathrm{~km}$ from Krakow. At this distance metal concentrations in the sediments from rainwater reservoirs were diminishing several times, which suggests considerable effect of urban pollution on metal level in these sediments.
\end{abstract}

Keywords: sediments from roads, stormwater ponds, lead, cadmium mercury

Environmental transformation conducted by humans is connected with growing number of hardened areas. Landscape anthropization and covering large areas with hardened surfaces results in disturbing the natural water cycling in the environment [1]. Disrupting the dynamic equilibrium between precipitations, water seepage, outflow and evaporation caused by the terrain sealing of leads to diminished water retention and intensified flood phenomena during torrential rains. It has been estimated that in natural ecosystems the amount of seeping water reaches $95 \%$, whereas in urbanized areas it is on average $30 \%$.

\footnotetext{
${ }^{1}$ Department of Agricultural and Environmental Chemistry, University of Agriculture in Krakow, al. A. Mickiewicza 21, 31-120 Kraków, Poland, phone +48 1266243 47, fax +48 1266248 41, email: niemiecm@o2.pl
} 
In city centers, $100 \%$ of water flows from the parking lots, roads and highways into to surface waters. The environmental effects of surface hardening involve intensification of flood phenomena caused by a large wave of surface runoffs to the receiver connected with destruction of the riverbed, occasionally increased river pollution because of an inflow of a large pollutant load supplied with torrential rain runoffs, lowering of the lowest water level in watercourses leading to the disappearance of water due to lack of feeding by ground waters and reduction or disappearance of plant and animal life in rivers. Considerable amounts of sewage flowing from the hardened areas pose a grave problem because of the necessity of their disposal as they may contain high amounts of pollutants [2, 3]. Rainwater runoff originating from urbanized areas contains over 600 various xenobiotics which may threaten the environment [4]. The most important pollutants of the runoffs from urbanized areas are organic matter, heavy metals, oil derivatives, chlorides or compounds extracted with petroleum spirit [5]. Due to fast development of transport and urbanization, a negative effect of sewage discharge from storm drainage systems on the neighboring water reservoirs was observed in the second half of the twentieth century. Increasing the amount and concentration of storm wastewater made necessary to make efforts at the wastewater management. Among the methods of storm wastewater disposal are evaporating reservoirs, retention and retention-infiltration reservoirs and sedimentation tanks. These structures are used for collecting the runoff flow and its gradual discharge into the reservoir. Natural processes of water self-purification in result of suspension sedimentation and pollutant absorption on also takes place in the reservoirs. Lead, cadmium and mercury are the most dangerous metals due to their considerable toxicity and common occurrence in the environment. Numerous scientific publications report substantial contents of these elements in rainwater runoffs from roads and highways posing hazard to surface water ecosystems $[6,7]$.

The investigations aimed at determining the contents of lead, cadmium and mercury in the sediments in reservoirs collecting rainwater flowing from the road and situated along the Sulkow-Suchoraba section of the national road 4.

\section{Materials and methods}

In 2007 and 2008 sediments were collected from water reservoirs which are receivers of rainwater runoff from the national road 4 along the $10 \mathrm{~km}$ section between Sulkow and Suchoraba villages. Technical parameters of the reservoirs and the catchment were given in Table 1. The samples were collected in May 2007, in April 2008 and in June 2008. Analyzed were the sediments from 11 reservoirs situated in the following villages: Sulkow (3 reservoirs), Biskupice (1 reservoir), Bodzanow (2 reservoirs) and Suchoraba (4 reservoirs). The sediments were collected from the top layer to the depth of $10 \mathrm{~cm}$. The collected sediments were air-dried, dry mineralized in a muffle furnace at $450^{\circ} \mathrm{C}$ and digested in a mixture of $\mathrm{HClO}_{4}$ and $\mathrm{HNO}_{3}$ acids (2:3 volumetric ratio). Material prepared in this way was dissolved in $\mathrm{HCl}$ and cadmium and lead concentrations were determined using ICP-AES method in JY 238 Ultrace apparatus (Jobin Yvon emission). Mercury content was assessed in air-dried sediments using AMA 254 spectrometer. Certified reference material CRM 16-050 was used to check the correctness of analyses of the studied elements. In the (Table 2) presents results of analyses of the reference material and an estimated value of recovery, based on analyses conducted in 4 replications. 
Characteristic of researched stormwater ponds

\begin{tabular}{|c|c|c|c|c|c|c|}
\hline \multirow{2}{*}{$\begin{array}{c}\text { No. of } \\
\text { object }\end{array}$} & \multirow{2}{*}{$\begin{array}{c}\text { Localisation } \\
\text { of reservoir }\end{array}$} & $\begin{array}{c}\text { Capacity } \\
\text { of reservoir }\end{array}$ & $\begin{array}{c}\text { Time of retention } \\
\text { of water in reservoir } \boldsymbol{t}\end{array}$ & $\begin{array}{c}\text { Hardened } \\
\text { terrains } \\
\boldsymbol{F}_{\mathbf{1}}\end{array}$ & $\begin{array}{c}\text { Green } \\
\text { terrains } \\
\boldsymbol{F}_{\mathbf{2}}\end{array}$ & $\begin{array}{c}\text { Flow } \\
\boldsymbol{Q}\end{array}$ \\
\cline { 5 - 7 } & & {$\left[\mathbf{m}^{\mathbf{3}}\right]$} & {$[\mathbf{m i n}]$} & 0.29 & 1.85 & 71 \\
\hline 1 & Sulkow & 118.4 & 31.1 & 0.29 & 5.97 & 119 \\
\hline 2 & Sulkow & 176.9 & 29.4 & 0.18 & 2.67 & 58 \\
\hline 3 & Sulkow & 86.2 & 29.7 & 0.39 & 2.58 & 77 \\
\hline 4 & Biskupice & 93 & 24.2 & 0.17 & 1.29 & 45 \\
\hline 5 & Przebieczany & 81.5 & 37.8 & 0.62 & 0.69 & 87 \\
\hline 6 & Bodzanow & 98 & 25.8 & 0.39 & 4.08 & 127 \\
\hline 7 & Bodzanow & 127 & 30.4 & 0.36 & 2.64 & 95 \\
\hline 8 & Suchoraba & 101.6 & 27.2 & 0.37 & 3.88 & 94 \\
\hline 9 & Suchoraba & - & - & 0.36 & 5.17 & 119 \\
\hline 10 & Suchoraba & 194.8 & 32 & 0.53 & 9.91 & 156 \\
\hline 11 & Suchoraba & 218 & 27.7 & & & \\
\hline
\end{tabular}

Table 2

Parameters of analysis method

\begin{tabular}{|c|c|c|c|c|c|}
\hline \multirow[t]{2}{*}{ Parameters } & Wavelengths & Limit detection & $\begin{array}{c}\text { Content } \\
\text { in certificated material }\end{array}$ & Measured & Recovery \\
\hline & [nm] & {$\left[\mathrm{mg} \cdot \mathrm{kg}^{-1}\right]$} & {$\left[\mathrm{mg} \cdot \mathrm{kg}^{-1}\right]$} & {$\left[\mathrm{g} \cdot \mathrm{kg}^{-1}\right]$} & [\%] \\
\hline $\mathrm{Pb}$ & 220.353 & 0.812 & 15 & 16.33 & 108.6 \\
\hline $\mathrm{Cd}$ & 228.802 & 0.040 & 0.4 & 0.426 & 106.5 \\
\hline $\mathrm{Hg}$ & 254.000 & 0.0004 & 0.13 & 0.132 & 101.9 \\
\hline
\end{tabular}

\section{Results and discussion}

Heavy metals are usual components of rainwater. Emission of these elements is connected will all kinds of human activity. Metals emitted into the atmosphere and absorbed on dust particles fall to the ground surface and are washed out by rainwater. Strongly athropogenically transformed catchments are characterized by a fast water runoff and concentration of storm wastewater within a small area. Rainfall wastewater discharged into small reservoirs may pose a serious hazard to local ecosystems because of toxic compounds entering food chain, therefore more and more frequently attention is focused on potential contamination of anthropogenic water reservoirs. Communication routes are the most dangerous for the environment. Concentrations of heavy metals and other pollutants from roads and highways are generally much higher than from city areas or compact suburban built-up areas. The quantity and forms in which heavy metals find their way into the environment depend on the traffic density, kind of surface and its liability to washing out and on the method of road drainage. A majority of heavy metals which enter water with surface runoffs binds to the suspension and, if sedimentation conditions are favourable, are carried to the sediments $[2,8,9]$. Immobilizing toxic compounds in sediments is a good way to protect surface waters in the vicinity of communication routes with considerable traffic capacity $[10,11]$.

Lead content in the sediments of the analyzed reservoirs ranged from 9.87 to $61.37 \mathrm{mg} \cdot \mathrm{kg}^{-1} \mathrm{~d} . \mathrm{m}$. (Table 3). The highest concentrations were assessed in the sediments 
collected in June 2008, whereas the lowest in the sediments collected in May 2008 (Fig. 1). Greater amounts of lead were observed in the reservoirs situated closer to Krakow. Mean content of this metal for all sampling dates from 6 reservoirs situated closest to the city was more than half higher than the same value for the reservoirs localized at a further distance from Krakow. Changeability of this element content in individual reservoirs was constant reaching about $36 \%$ in all studied sediments. The amounts of lead in the investigated sediments were small and did not exceed the admissible lead contents in the soil or earth under protection [12], therefore it may be said that this element poses no hazard to the environment. Lead occurs commonly in surface runoffs. It originates both from fuel burning and vehicles operation, but also from abrasion of tires and asphalt surfaces. Considerable amounts of this element were also registered in the runoffs during the period when petrol was enriched with lead tetrachloride, however Ball et al [13] stated that despite abandoning fuel lead supplements, traffic remains a serious source of this element. The same researchers observed considerably exceeded admissible values of lead in runoffs from the roads in Norway. Values of lead concentrations in sediments of the investigated reservoirs were not high and much lower than reported in literature. Smith [14] found this element concentrations reaching 231-286 $\mathrm{mg} \cdot \mathrm{kg}^{-1}$ in runoffs from American cities. Datry et al [15] determined this element content in the sediments from infiltration basins for rain runoffs in the vicinity of Lyon on the level of 623-1148, whereas Petavy et al [10] noted lead concentrations in the sediments from roads in western France ranging from $183-424 \mathrm{mg} \cdot \mathrm{kg}^{-1}$. Birch and McCready [16] reported lead content in the sediments originating from urbanized areas in Sydney on the level of $880 \mathrm{mg} \cdot \mathrm{kg}^{-1}$, while Murakami et al [17] determined this metal level in the sediments from runoffs from the roads in Tokyo up to $210 \mathrm{mg} \cdot \mathrm{kg}^{-1}$.

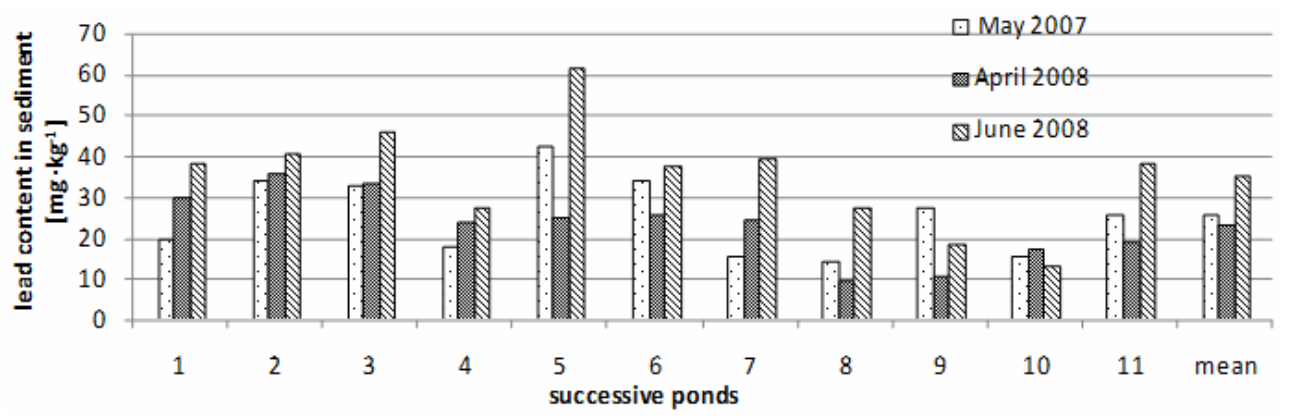

Fig. 1. Lead content in sediment from rainfall ponds

Jartun et al [18] reported mean content of lead in the sediments of runoffs in Bergen, Norway on the level of $126 \mathrm{mg} \cdot \mathrm{kg}^{-1}$. On the other hand Krolikowski et al [19] registered average lead contents in the sediments from rain inlets in Bialystok on the level of $13-44 \mathrm{mg} \cdot \mathrm{kg}^{-1}$, but the amounts of this element in the sediments from retention basins ranged between 50 and $300 \mathrm{mg} \cdot \mathrm{kg}^{-1}$. Jagus et al [20] found lead concentrations between 15 and $16 \mathrm{mg} \cdot \mathrm{kg}^{-1}$ in the bottom sediments of the Irkutsk reservoir. Small content of lead in the sediments from the analyzed reservoirs may result from dilution of these pollutants by the material eroded from the catchment area or poor sedimentation conditions in result of 
which the finest suspension fraction is drained to the reservoirs together with considerable amounts of metals.

Table 3

Characteristic of researched stormwater ponds

\begin{tabular}{|c|c|c|c|c|c|c|}
\hline \multirow[t]{2}{*}{ Element } & \multirow{2}{*}{$\begin{array}{c}\text { Successive } \\
\text { sampling }\end{array}$} & $\min$ & $\max$ & mean & median & \multirow{2}{*}{$\begin{array}{c}\begin{array}{c}\text { Variability } \\
\text { coefficient }\end{array} \\
{[\%]}\end{array}$} \\
\hline & & \multicolumn{4}{|c|}{$\left[\mathrm{mg} \cdot \mathrm{kg}^{-1}\right.$ d.m. $]$} & \\
\hline \multirow{3}{*}{$\mathrm{Pb}$} & I & 14.21 & 42.58 & 25.56 & 25.75 & 37 \\
\hline & II & 9.87 & 36.00 & 23.32 & 24.64 & 36 \\
\hline & III & 13.06 & 61.37 & 35.35 & 38.18 & 38 \\
\hline \multirow{3}{*}{$\mathrm{Cd}$} & I & 0.20 & 1.21 & 0.551 & 0.5 & 55 \\
\hline & II & 0.238 & 1.58 & 0.621 & 0.55 & 61 \\
\hline & III & 0.294 & 1.30 & 0.738 & 0.769 & 37 \\
\hline \multirow{3}{*}{$\mathrm{Hg}$} & $\mathrm{I}$ & 0.0337 & 0.837 & 0.141 & 0.059 & 166 \\
\hline & II & 0.0420 & 0.643 & 0.11 & 0.089 & 110 \\
\hline & III & 0.0379 & 0.864 & 0.162 & 0.083 & 149 \\
\hline
\end{tabular}

Mean concentration of cadmium in the analyzed sediments from rainwater reservoirs was $0.637 \mathrm{mg} \cdot \mathrm{kg}^{-1}$ and fluctuated from 0.2 to $1.58 \mathrm{mg} \cdot \mathrm{kg}^{-1}$ (Table 3). Similarly as for lead, the smallest quantities of $\mathrm{Cd}$ were found in the sediments collected during the first sampling, whereas the highest were assessed in the sediments taken in June 2008 ( $3{ }^{\text {rd }}$ sampling). The highest quantities of this element were assessed in the reservoirs situated in the closest vicinity of Krakow (Fig. 2). Average for the three samplings from objects 1-6 was $0.805 \mathrm{mg} \cdot \mathrm{kg}^{-1}$, whereas for reservoirs $7-11$ it reached $0.435 \mathrm{mg} \cdot \mathrm{kg}^{-1}$. With growing distance from the agglomeration cadmium level in the sediments was falling regularly. Relative standard deviation for sediments from all reservoirs fluctuated between 37 and $60 \%$, it was the lowest for the first sampling and the highest for the third. Cadmium quantities in the studied sediments were low and did not pose any hazard to the environment because they did not exceed admissible contents in the soil or earth under protection [12]. Rozenkratz et al [4] reported similar cadmium contents on the level of $0.6-1.9 \mathrm{mg} \cdot \mathrm{kg}^{-1}$ in the infiltration basins of rainwater in the Melbourne environs, whereas Datry et al [15] determined this metal content in the sediments from infiltration basins of rainwater runoffs in the vicinity of Lyon within the $1.3-3.8 \mathrm{mg} \cdot \mathrm{kg}^{-1}$ range. Petavy et al [10] found cadmium concentrations between 0.6 and $0.8 \mathrm{mg} \cdot \mathrm{kg}^{-1}$ in infiltration basins in western France, depending on fraction size. Krolikowski et al [19] obtained lower results, on the level of $0.12-0.26 \mathrm{mg} \cdot \mathrm{kg}^{-1}$, for cadmium concentrations in the sediments from rainwater inlets.

Jartun [18] reports an average cadmium content in the sediments from rainwater runoffs in Bergen environs on the level of $1.3 \mathrm{mg} \cdot \mathrm{kg}^{-1}$. Cadmium registered in rainwater runoffs from roads and highways originates primarily from tires abrasion, whereas some amounts enter the environment from liquid fuel burning. The results of cadmium content in the sediments of analyzed reservoirs are approximate to its amounts registered in reservoirs in different cities in the world.

Because of its specific cycling in the environment, mercury is always a component of rainwater. This element compounds fall and find their way to surface waters during rainfall. 


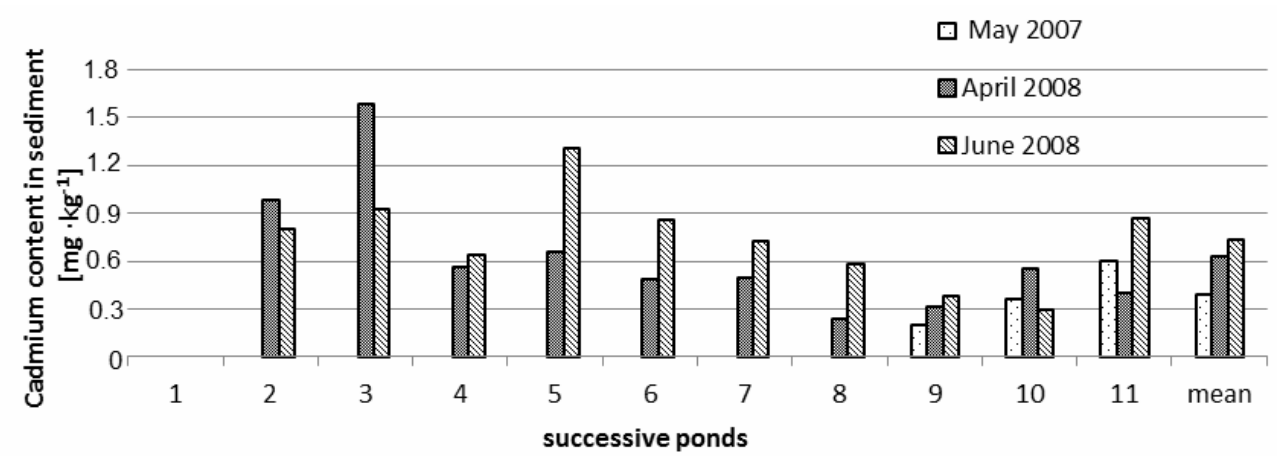

Fig. 2. Cadmium content in sediment from rainfall ponds

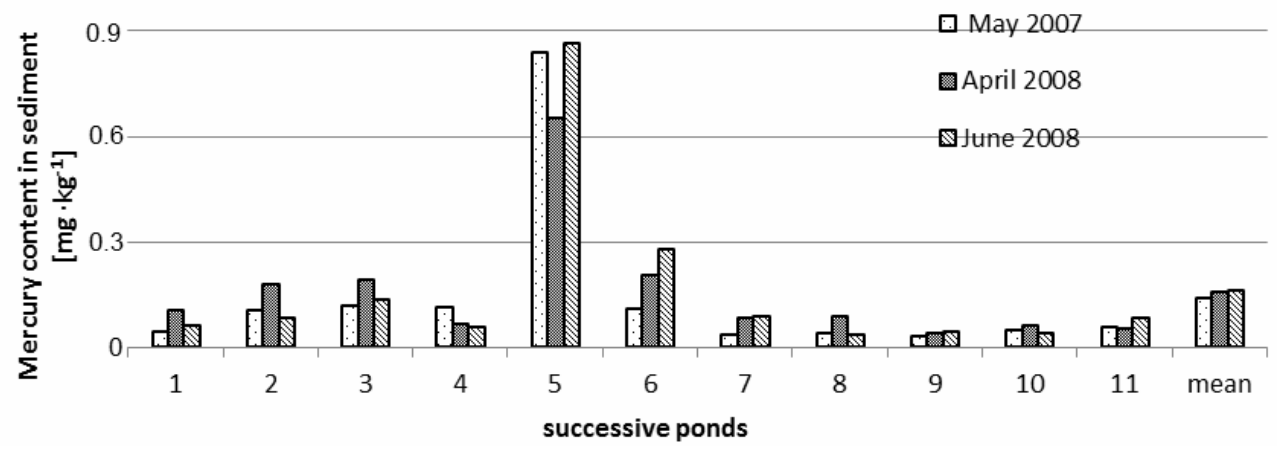

Fig. 3. Mercury content in sediment from rainfall ponds

The most important anthropogenic sources of mercury in the environment are burning of coal and liquid fuels and some industries (eg chlorine production). Small amounts also leach from road surfaces. Checking this element amounts in road runoffs is extremely important because of potential enrichment of surface water used for fish farming [21]. In many agglomerations rainwater is collected in reservoirs of surface waters which are used for recreation, eg for angling. Mercury is an element easily bioaccumulated in water environment, therefore it poses a hazard to people who eat fish. At considerable mercury deposition it may accumulate in bottom deposits together with falling suspensions. Mercury, temporarily immobilized in bottom sediments, may be mobilized and provide a serious source of this element. Tomyiasuet al [21] found mercury contents on the level of ca $3.7 \mathrm{mg} \cdot \mathrm{kg}^{-1}$ in the top layer of sediments in Minamata Bay. The same authors stated that bottom deposits still provide a serious source of mercury in Minamata Bay waters despite the fact that presently there is no emission of this element in this region. Mercury in sediments does not remain long on the same level, therefore at moderate amounts of this element finding their way to the environment no increased concentrations in sediments have been observed. Urlih et al [22] conducted research on mercury accumulation in water ecosystem of the Nura River in central Kazakhstan, which is the region most seriously contaminated with sewage from acetaldehyde factory in this country. The researchers found mercury concentrations in the river below the factory on the level exceeding $0.3 \mathrm{mg} \cdot \mathrm{kg}^{-1}$, 
whereas the concentrations in the river sediments $2 \mathrm{~km}$ below the factory were $96 \mathrm{mg} \cdot \mathrm{kg}^{-1}$. The value in the sediments above the factory was $0.006 \mathrm{mg} \cdot \mathrm{kg}^{-1}$. At so high mercury concentrations in water and sediments this metal accumulation in fish muscles increases even to $0.8 \mathrm{mg} \cdot \mathrm{kg}^{-1}$ of fresh mass. It is a serious hazard to potential fish consumers. Mercury amounts assessed in sediments from rainwater reservoirs ranged between 0.0337 and $0.864 \mathrm{mg} \cdot \mathrm{kg}^{-1}$ (Table 3). Like in case of lead and cadmium the highest amounts were found in sediments collected in June 2008 and the lowest in June 2007 (Fig. 3).

Irrespective of the sampling date, the highest concentrations of mercury were noted in sediments collected from reservoirs localized in the closest vicinity to Krakow. Mean content of this element in 6 reservoirs closest to Krakow was over 4 times higher than average content in the other reservoirs situated further from the city. Considerable amounts of mercury were found in the reservoir in Przebieczany village. It indicates possible point source pollution with this element. Rosenkrantz et al [4] found very low concentrations of this element, below $0.05 \mathrm{mg} \cdot \mathrm{kg}^{-1}$ in the sediments from urban areas of Melbourne, whereas the other metal contents in these sediments were very high. Jartun et al [18] determined mercury content in the sediments from runoffs in the vicinity of Bergen for $2.81 \mathrm{mg} \cdot \mathrm{kg}^{-1}$ at an average of $0.8 \mathrm{mg} \cdot \mathrm{kg}^{-1}$, whereas Schiff and Bay [23] registered these element concentrations in Ballona and Malibu Bays in Santa Monica on the level of $0.018-0.08 \mathrm{mg} \cdot \mathrm{kg}^{-1}$. Both bays remain under strong influence of the city. Mercury content in the sediments from the analyzed reservoirs were approximate to the quantities assessed in the sediments from the runoffs from anthropogenic areas reported by other authors.

\section{Conclusions}

1. Considerable differences were assessed in the contents of lead, cadmium and mercury among the analyzed reservoirs, irrespective of the distances between them.

2. Differences in concentrations were observed with respect to sampling date, however the trends of differences were similar at each sampling.

3. Lead contents in the sediments from evaporation reservoirs were considerably smaller than this element amounts noted in rainwater reservoirs in other cities in the world.

4. Concentrations of cadmium and mercury observed in the analyzed sediments were comparable to this element content in rainwater sediments from other places of the earth.

5. With growing distance from Krakow agglomeration concentrations of all investigated metals were diminishing, which evidences a considerable share of pollutants originating in the city and transported by the wind.

\section{References}

[1] Skwierawski A, Sidoruk M. Ecol Chem Eng S. 2014;21(1):79-88. DOI: 10.2478/eces-2014-0007.

[2] Vaze J, Chiew FHS. J Environ Eng. 2004;130(4):391-396. DOI: 10.1061/(ASCE)07339372(2004)130:4(391).

[3] Chmielewska A, Widomski MK, Musz M, Łagód G, Mazurek W. Ecol Chem Eng A. 2013;20(12):1397-1410. DOI: 10.2428/ecea.2013.20(12)126.

[4] Rosenkrantz RT, Pollino CA, Nugegod D, Baun A. Environ Pollut. 2008;156(3):922-927. DOI: 10.1016/j.envpol.2008.05.013. 
[5] Khan E, Khaodhir S, Ruangrote D. Bioresour Technol. 2009;100(9):4454-4461. DOI: 10.1016/j.biortech.2008.12.062.

[6] Barret ME, Zuber RD, Collins ER. A Review and Evaluation of Literature Pertaining to the Quality and Control of Pollution from Highway Runoff and Construction. Center for Research in Water Resources. Austin, USA: The University of Texas at Austin; 1995.

[7] Lee PK, Touray JC, Baillif P, Ildefonse JP. Sci Total Environ. 1997;201:1-15. DOI: 10.1016/S0048-9697(97)84048-X.

[8] Niemiec M, Arasimowicz M, Wiśniowska-Kielian B. Ecol Chem Eng A. 2012;19(10):1221-1228. DOI: 10.2428/ecea.2012.19(10)116.

[9] Niemiec M, Wiśniowska-Kielian B, Arasimowicz M. Ecol Chem Eng A. 2012;19(1-2):113-121. DOI: 10.2428/ecea.2012.19(01)012.

[10] Pétavy F, Ruban V, Conil P. Chem Eng J. 2009;145(3):475-482. DOI: 10.1016/j.cej.2008.04.039.

[11] Wiśniowska-Kielian B, Niemiec M, Arasimowicz M. Ecol Eng. 2013;34:62-75. DOI: $10.12912 / 23920629 / 321$.

[12] Regulation of the Minister of the Environment on soil quality standards and earth quality standards (Polish Journal of Laws DzU 2002 No. 165, item 1359 of 4 October 2002). http://isap.sejm.gov.pl/DetailsServlet?id=WDU20021651359.

[13] Ball JE, Wojcik A, Tilley J. Stormwater Quality from Road Surfaces - Monitoring of the Hume Highway at South Strathfield. New South Wales: University of New South Wales; 2000.

[14] Smith E. Water Res. 2001;35(13):3117-3126. DOI: 10.1016/S0043-1354(01)00008-2.

[15] Datry T, Malard F, Vitry L, Hervant F, Gibert J. J Hydrol. 2003;273(1-4):217-233. DOI: 10.1016/S0022-1694(02)00388-8.

[16] Birch GF, McCready S. Sci Total Environ. 2009;407(8):2820-2835. DOI: 10.1016/j.scitotenv.2008.12.051.

[17] Murakami M, Nakajim F, Furumai H. Chemosphere. 2008;70(11):2099-2109. DOI: 10.1016/j.chemosphere.2007.08.073.

[18] Jartun M, Ottesen RT, Steinnes E, Volden T. Sci Total Environ. 2008;396(2-3):147-163. DOI: 10.1016/j.scitotenv.2008.02.002.

[19] Królikowski A, Grabarczyk K, Gwoździej-Mazur J, Butarewicz A. Sediments Forming in Objects of Rainwater Drainage System. Bialystok: Monografie PAN; 2006;34:110-145.

[20] Jaguś A, Khak V, Rzętała M, Rzętała M. Ecol Chem Eng A. 2012;19(8):939-950. DOI: 10.2428/ecea.2012.19(08)09.

[21] Tomiyasu T, Matsuyama A, Eguchi T, Marumoto K, Oki K, Akagi H. Mar Chem. 2008;112(1-2):102-106. DOI: 10.1016/j.marchem.2008.07.003.

[22] Ullrich SM, Ilyushchenko MA, Uskov GA, Tanton TW. Appl Geochem. 2007;22(12):2706-2734. DOI: 10.1016/j.apgeochem.2007.07.005.

[23] Schiff K, Bay S. Mar Environ Res. 2003;56(1-2):225-243. DOI: 10.1016/S0141-1136(02)00332-X.

\title{
ZAWARTOŚĆ OŁOWIU KADMU I RTECCI W OSADACH ZE ZBIORNIKÓW WÓD OPADOWYCH ZLOKALIZOWANYCH WZDEUŻ DROGI KRAJOWEJ NR 4
}

\author{
Katedra Chemii Rolnej i Środowiskowej, Uniwersytet Rolniczy im. Hugona Kołłątaja w Krakowie
}

\begin{abstract}
Abstrakt: Celem pracy było określenie poziomu zanieczyszczenia osadów pobranych ze zbiorników przyjmujących wody deszczowe. Osady pobrano z 11 zbiorników w trzech terminach: maj 2007 r., kwiecień 2008 r. i czerwiec 2008 r. z miejscowości: Sułków, Biskupice, Bodzanów i Suchoraba na odcinku ok. 15 km. W osadach oznaczono zawartość ołowiu, kadmu, rtęci oraz materii organicznej. Zawartość ołowiu w badanych osadach kształtowała się w granicach $9,87-61 \mathrm{mg} \cdot \mathrm{kg}^{-1}$. Średnia dla wszystkich próbek wynosiła $28,08 \mathrm{mg} \cdot \mathrm{kg}^{-1}$. Średnie stężenie kadmu w badanych osadach wynosiło $0,637 \mathrm{mg} \cdot \mathrm{kg}^{-1} \mathrm{i}$ wahało się w granicach 0,20-1,58 $\mathrm{mg} \cdot \mathrm{kg}^{-1}$. Ilości rtęci oznaczone w osadach ze zbiorników wód opadowych mieściły się od 0,0337 do $0,864 \mathrm{mg} \cdot \mathrm{kg}^{-1}$. Stwierdzono znaczne różnice stężeń badanych metali pomiędzy poszczególnymi zbiornikami, jednak trendy różnic w każdym poborze były podobne. Generalnie poziomy kadmu i rtęci w badanych osadach były porównywalne do osadów ze spływów z terenów zurbanizowanych różnych miast na świecie, natomiast poziom ołowiu w osadach badanych zbiorników był generalnie dużo niższy niż podają dane literaturowe dla podobnych materiałów. Zaobserwowano regularne zmniejszanie zawartości wszystkich
\end{abstract}


pierwiastków w miarę oddalania się od aglomeracji krakowskiej. Zbiornik usytuowany najbliżej Krakowa w Sułkowie oddalony jest o ok. $7 \mathrm{~km}$ od rogatek Krakowa i znajduje się przy granicy z miastem Wieliczka, natomiast zbiornik w Suchorabie jest oddalony o ok. $17 \mathrm{~km}$ od Krakowa. Na tej odległości zawartość metali w osadach ze zbiorników wód deszczowych zmniejszała się kilkukrotnie, co sugeruje znaczny wpływ zanieczyszczeń miejskich na poziom metali w osadach.

Słowa kluczowe: osady z dróg, zbiorniki wód opadowych, ołów, kadm, rtęć 